\title{
Purification and Partial Characterization of a Lectin from the Fresh Leaves of Kalanchoe crenata (Andr.) Haw
}

\author{
Kuku Adenike* and Oladiran Babalola Eretan \\ Department of Biochemistry, Obafemi Awolowo University, Ile-Ife, Nigeria
}

Received 28 May 2003, Accepted 15 July 2003

\begin{abstract}
A haemagglutinating protein from the saline extracts of Kalanchoe crenata leaves, which agglutinate all human blood types, was purified to homogeneity by ion-exchange chromatography on a DEAE-Cellulose column followed by gel filtration on a Sephadex G-100 column. The purified protein showed one band, both in non-denaturing PAGE and SDS-PAGE. The $M_{r}$ that was determined by SDSPAGE was 44,000 Da and that estimated from gel filtration was 47,000. Treatment of the haemagglutinating protein with $5 \mathrm{mM}$ EDTA diminished the haemagglutinating activity to $50 \%$ of the original level. The addition of

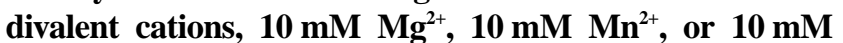
$\mathrm{Ba}^{2+}$, totally restored and enhanced the activity. The protein showed maximum activity over the 3-7 $\mathrm{pH}$ range and was heat-resistant. It was also a glycoprotein containing about $1.5 \%$ carbohydrate.
\end{abstract}

Keywords: Kalanchoe crenata, Leaves, Lectin, Saxifragaceae

\section{Introduction}

Lectins are carbohydrate-binding proteins that are widely distributed in the plant kingdom. This class of proteins has been isolated from many plants and animals. Their characteristics have also been extensively exploited in many aspects of biochemistry and biomedicine (Pusztai, 1993). In plants, leguminous seeds are a particularly rich source of lectins, while only a few have been isolated from other families (Dong et al., 1993; Cavada et al., 1998).

The main properties of lectins are based on their ability to interact with carbohydrates and thus combine with glycocomponents on the cell surface, leading to their biological properties (Goldstein and Poretz, 1986). Lectins are

*To whom correspondence should be addressed.

E-mail: takuku@oauife.edu.ng; adenikekuku@yahoo.com able to tightly bind to and cause the precipitation of specific polysaccharides and glycoproteins because they are polyvalent (i.e. each lectin molecule has at least two carbohydrate binding sites to allow cross-linking between the cells or between the sugars containing the macromolecules). These lectins vary, however, in molecular size, amino acid composition, metal ion requirements, and three-dimensional structure (Sharon, 1993).

Most of the lectins that were examined contained metal ions, $\mathrm{Mn}^{2+}$ and/or $\mathrm{Ca}^{2+}$. In some cases, evidence has been presented for the requirement of the metal ions for activity. Interaction with carbohydrates by these molecules requires tightly bound $\mathrm{Ca}^{2+}$ and $\mathrm{Mn}^{2+}$ (or another transition metal ion). These metal ions are located close to the carbohydrate-binding site and are identically positioned. Thus, metal ions serve to maintain the integrity of the subunits of the lectins, and in addition, help to position amino acid residues for carbohydrate binding (Lis and Sharon, 1989).

The isolation and characterization of non-leguminous lectins is of importance in order to study the minor structural differences that can lead to dramatic differences in biological properties and also to investigate the ubiquitous nature of the lectins. The isolation and partial characterization of a lectin from the leaves of Kalanchoe crenata is described here. The plant is from the Saxifragaceae family and Crassulaceae tribe that are widely found in temperate and tropical regions. In southwestern Nigeria, the juice from the leaves is traditionally used to treat a wide range of ailments. These include earaches, headaches, general debilities, convulsions, stiff joints, and rheumatism. The juice, in addition, is also employed as a general antidote to poison (Dalziel, 1955).

\section{Materials and Methods}

$K$. crenata leaves were obtained from the surroundings of the Biological Sciences Building of the Obafemi Awolowo University, Ile-Ife, and were taxonomically identified in the Herbarium of the Department of Botany of the University. Human blood cells from the 
Table 1. Summary of purification procedures

\begin{tabular}{ccccc}
\hline Fraction & Protein $(\mathrm{mg})$ & Total activity & Specific activity & Yield $(\%)$ \\
\hline Crude extract & 4839 & 16.4 & 3.38 & 100 \\
DEAE-Cellulose & 109.3 & 0.5 & 4.69 & 3.13 \\
Sephadex G-100 & 7.33 & 0.06 & 8.73 & 0.3 \\
\hline
\end{tabular}

$\mathrm{ABO}$ system were obtained from healthy donors in the Department of Biochemistry, Obafemi Awolowo University, Ile-Ife. Acrylamide, Methylenebisacrylamide, DEAE-Cellulose, and all of the sugars were products of Sigma (St. Louis, USA). The Sephadex G-100 and molecular weight markers were from Pharmacia (Uppsala, Sweden). All of the other reagents were of analytical grade.

Lectin extraction $K$. crenata leaves were washed and sliced into small pieces. Then $100 \mathrm{~g}$ of the sliced leaves were homogenized in a blender with $150 \mathrm{ml}$ of phosphate buffered saline (PBS), pH 7.2, with and without $\varepsilon$-amino-n-caproic acid. The solution was collected, filtered, and stored at $-20^{\circ} \mathrm{C}$.

Protein concentration The protein concentration was determined by the method described by Gornall et al. (1949) using bovine serum albumin (BSA) as the standard.

Haemagglutinating activity Agglutination of the red blood cells by the crude extract and various fractions that were obtained during purification was estimated as described before by Bing et al. (1967). In a U-shaped microtitre plate arranged in rows of wells, $1: 2$ dilutions of the sample in PBS buffer were mixed with $50 \mu \mathrm{l}$ of $2 \%$ suspension of erythrocytes. The plate was left undisturbed for $30 \mathrm{~min}$ to $1 \mathrm{~h}$ at room temperature in order to allow for agglutination of the erythrocytes to take place. The titre of the lectin was expressed as the reciprocal of the highest dilution showing visible agglutination of erythrocytes. Specific activity was expressed as haemagglutination units (HU)/mg or as the minimum concentration of protein $(\mu \mathrm{g} / \mathrm{ml})$ still giving activity (Table 1$)$.

Blood group specificity The blood group specificity of the extract was established using erythrocytes from different blood groups of the $\mathrm{ABO}$ system.

Sugar specificity The sugar specificity of the lectin was investigated by the ability of a series of simple sugars to inhibit the agglutination of human erythrocytes. Two-fold dilutions of sugar (0.2 M initial concentration) solutions in PBS were mixed with $0.1 \mathrm{ml}$ of the lectin solution $(3.2 \mathrm{mg} / \mathrm{ml})$ and allowed to react for 30 $\mathrm{min}$ at room temperature. An erythrocyte suspension $(0.05 \mathrm{ml})$ was then added and the mixture left for another $30 \mathrm{~min}$. The haemagglutinating titres that were obtained were compared with a non-sugar containing blank. In this study, the following sugars were used: D-glucose, D-galactose, D-melibiose, cellobiose, D-arabinose, Lactose, Trehalose, L-sorbose, D-xylose, D-glucosamine, 2-deoxyD-glucose, and $\alpha$-methyl-D-glucopyranoside.

Polyacrylamide gel electrophoresis Polyacrylamide gel electrophoresis in the absence and presence of SDS was performed on $10 \%$ gels on either the rod or slab apparatus in a Tris-glycine buffer, $\mathrm{pH} 8.9$, according to the Pharmacia manual. The proteins were stained with Coomassie Brilliant Blue R, while the presence of covalently bound sugar in the lectin was detected by staining the gels with Periodic Acid Schiff reagent (PAS staining), as described in the Pharmacia Manual (Polyacrylamide Gel Electrophoresis Laboratory Techniques, revised edition, 1983).

Molecular weight determination The apparent molecular weight of the lectin was estimated under non-denaturing conditions by gel filtration on a Sephadex G-100 column $(2.5 \times 100 \mathrm{~cm})$ using the following protein markers: $\alpha$-chymotrypsinogen $\mathrm{A}\left(M_{r} 25,000\right.$, $3 \mathrm{mg} / \mathrm{ml})$, Bovine serum albumin $\left(M_{r} 66,000,3 \mathrm{mg} / \mathrm{ml}\right)$, Ovine albumin $\left(M_{r} 45,000,3 \mathrm{mg} / \mathrm{ml}\right)$, and Thermolysin $\left(M_{r} 37,500,3 \mathrm{mg} /\right.$ $\mathrm{ml}$ ). One $\mathrm{ml}$ of each standard protein was applied to the column and ran separately using a $10 \mathrm{mM}$ phosphate buffer, $\mathrm{pH} 7.0$ as eluant at a flow rate of $8.4 \mathrm{ml} / \mathrm{h}$. Fractions of $2 \mathrm{ml}$ were collected and the elution was monitored for each protein at $280 \mathrm{~nm}$. The void volume $\left(\mathrm{V}_{\mathrm{o}}\right)$ of the column was determined using Blue Dextran (its elution being monitored at $620 \mathrm{~nm}$ ).

Estimation of the subunit molecular weight of the purified lectin was determined by SDS-polyacrylamide gel electrophoresis using the following protein markers: carbonic anhydrase $(29,000), \alpha-$ lactalbumin $(14,000)$, glyceraldehyde-5-phosphate dehydrogenase $(36,000)$, egg albumin $(45,000)$, and bovine serum albumin $(66,000)$.

Effect of EDTA and divalent cations The effect of EDTA and divalent cations on the haemagglutinating activity of the protein was carried out according to the method of Sampaio et al. (1998). Two-fold serial dilutions of lectin that were prepared in 0.2 M PBS alone and $0.2 \mathrm{M}$ PBS containing $5 \mathrm{mM}$ EDTA were carried out. Human erythrocytes (4\%) in $0.2 \mathrm{M}$ PBS with $5 \mathrm{mM}$ EDTA were used as the control. Equal volumes $(50 \mu \mathrm{l})$ of $10 \mathrm{mM} \mathrm{MgSO}_{4}$, $\mathrm{MnCl}_{2}$, or $\mathrm{BaCl}_{2}$ were later added to the haemagglutination assay that was performed in the presence of EDTA in order to evaluate their capacity to restore haemagglutination.

Effect of temperature on haemagglutinating activity The effect of temperature on the haemagglutinating activity was monitored, as described by Sampaio et al. (1998). Aliquots of lectin were incubated at different temperatures $\left(30-90^{\circ} \mathrm{C}\right)$. The heated solution was rapidly cooled in ice and assayed for agglutinating activity. Agglutinating activity of the control that was kept at $20^{\circ} \mathrm{C}$ for 30 min was used as a reference.

Effect of $\mathbf{p H}$ on haemagglutinating activity The effect of $\mathrm{pH}$ on the haemagglutinating activity was determined by carrying out the haemagglutinating assay of the lectin using the following buffers at different $\mathrm{pH}$ values; $0.2 \mathrm{M}$ glycine- $\mathrm{NaOH}$ buffer, $\mathrm{pH} 10-12 ; 0.2 \mathrm{M}$ citrate-phosphate buffer, $\mathrm{pH} 3-7$, and $0.2 \mathrm{M}$ borate buffer, $\mathrm{pH}$ 7.5- 


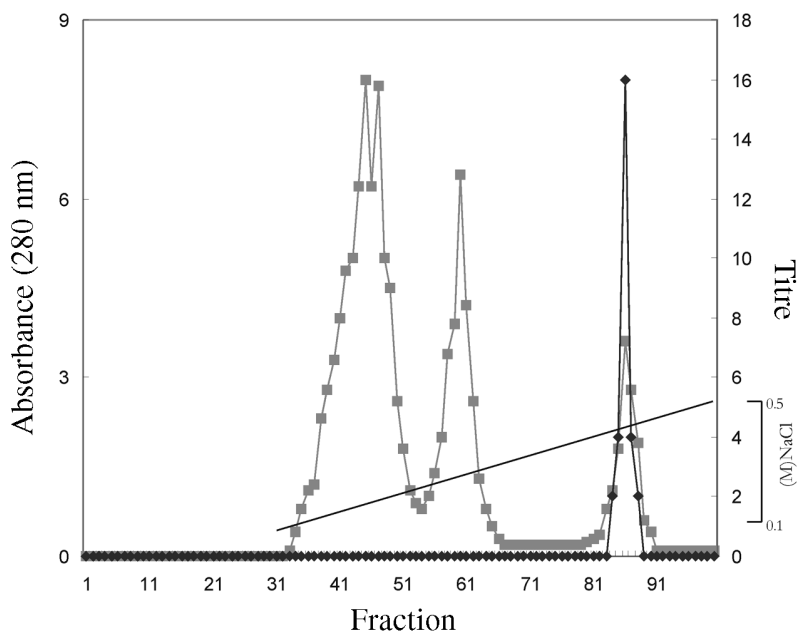

Fig. 1. DEAE-cellulose ion exchange chromatography of $K$. crenata extract. Eluant was PBS, $\mathrm{pH} 7.2$, followed by a linear 0.1$0.5 \mathrm{M} \mathrm{NaCl}$ gradient. Column size was $1.5 \times 35 \mathrm{~cm}$; Flow rate was $24 \mathrm{ml} / \mathrm{h}$ while the fraction size was $2 \mathrm{ml}$. (ם) Absorbance at $280 \mathrm{~nm},(\diamond)$ Agglutination titre, $(-) \mathrm{NaCl}$ gradient.

9.5. The control values were the agglutination titre of the lectin in PBS, pH 7.2.

\section{Results and Discussion}

Isolation of the lectin The isolation and purification of the lectin from the crude extract of the leaves was obtained by a two-step procedure. This involved an initial ion-exchange chromatography of the crude extract on DEAE-cellulose, carried out according to the method of Knight (1967) using a linear $0.1-0.5 \mathrm{M} \mathrm{NaCl}$ gradient (Fig. 1). The protein fractions, with the activity combined, constituted no more than $10 \%$ of the extractable soluble leaf proteins. In the second step, the fractions with the haemagglutinating activity from the first step were subjected to gel filtration on a Sephadex G-100 column (Fig. 2). The single peak that was obtained from the gel filtration contained all of the haemagglutinating activity and was a homogenous preparation, as indicated by the polyacrylamide gel electrophoresis (figure not shown). Table 1 summarizes the purification scheme for $K$. crenata lectin.

Properties of $\boldsymbol{K}$. crenata lectin The phosphate-buffered saline (PBS) extract of the $K$. crenata leaves agglutinate the human red blood cells of the ABO system at approximately the same dilution (non-specifically and fairly strongly). The $K$. crenata lectin may then be classified into the category of lectins that agglutinate erythrocytes of all human blood groups alike, which are usually referred to as non-specific lectins (Watkins et al., 1981). Moreira and co-workers (1998) found that the lectin from Artocarpus incisa L. agglutinates human erythrocytes of the ABO system. Also, PBS extracts of the seeds of Dioclea reflexa non-specifically agglutinate the

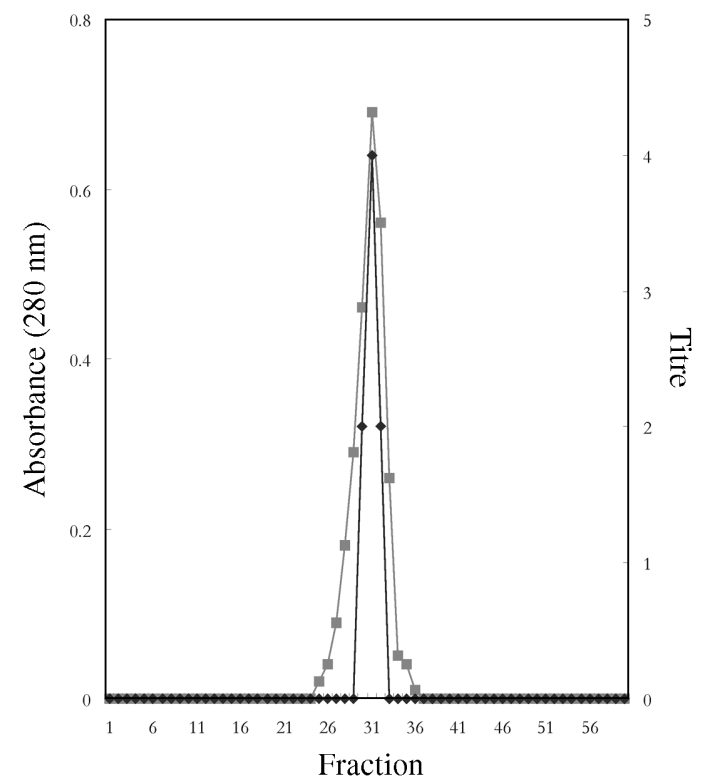

Fig. 2. Gel filtration of the active fractions from the DEAEcellulose column on Sephadex G-100 column. Eluant was PBS, $\mathrm{pH}$ 7.2. The flow rate was $20 \mathrm{ml} / \mathrm{h}$ and the fraction size was $2 \mathrm{ml}$. (ם) Absorbance at $280 \mathrm{~nm}$; ( ) Agglutination titre.

erythrocytes of human blood groups (Kuku et al., 2000), among all others.

Of the twelve sugars that were tested for their inhibitory activity, only melibiose, $6-\alpha-D$-galactosyl-D-glucose, showed inhibitory activity (Table 2). Therefore, it is relevant to observe that melibiose has been employed as a ligand in agarose-based affinity matrices for the purification of both Bandeiraea simplicifolia (BS-1) lectin (Hayes and Goldstein, 1974) and Arachis hypogea agglutinin (Lotan et.al., 1974) The latter lectin, as well as Agaricus bisporus lectin, shows specificity for the disaccharide $\beta$-D-gal $(1 \rightarrow 3)$-D-galNAc (Presant and Kornfeld, 1972). There is, however, the enigmatic enhancement of the haemagglutinating activity by both arabinose and the disaccharide, cellobiose.

The incubation of $K$. crenata lectin with $5 \mathrm{mM}$ EDTA significantly decreased the haemagglutinating activity. The addition of divalent cations (such as $\mathrm{Mg}^{2+}, \mathrm{Mn}^{2+}$, or $\mathrm{Ba}^{2+}$ to inhibited lectin aliquots) completely restored the activity (Table 3). Although no direct determination of the presence, identity, and amount of divalent metal ion in the native protein has been carried out, these results suggest that the lectin requires divalent ions for activity.

Molecular weight The $M_{r}$ of purified $K$. crenata lectin that was determined by gel filtration was $47,000 \mathrm{Da}$. SDS-PAGE showed a protein band with $M_{r} 44,000 \mathrm{Da}$. It would appear, therefore, that the native protein is monomeric in a manner that is similar to that observed for the lectins from A. bisporus (Presant and Kornfeld, 1972) and Tetracarpidium conophorum (Togun et al., 1994) and Dioclea reflexa (Adeyemi et al., 1994). The molecular weight of the native 
Table 2. Sugar inhibition of haemagglutination by Kalanchoe crenata extract

\begin{tabular}{lcc}
\hline \multicolumn{1}{c}{ Sugar } & Titre & $\begin{array}{c}\text { Minimum inhibitory } \\
\text { Concentration }\end{array}$ \\
\hline PBS control & $2^{12}$ & \\
D-Glucose & $2^{12}$ & No inhibition \\
D-Galactose & $2^{12}$ & No inhibition \\
D-Melibiose & $2^{2}$ & $100 \mathrm{mM}$ \\
Cellobiose & $2^{16}$ & Enhancement \\
Arabinose & $2^{15}$ & Enhancement \\
D-Lactose & $2^{12}$ & No inhibition \\
Trehalose & $2^{12}$ & No inhibition \\
L(-) Sorbose & $2^{12}$ & No inhibition \\
Xylose & $2^{12}$ & No inhibition \\
D(+) Glucosamine-hydrochloride & $2^{12}$ & No inhibition \\
2-deoxy-D-Glucose & $2^{12}$ & No inhibition \\
$\alpha$-methyl-D-glucopyranoside & $2^{12}$ & No inhibition \\
\hline
\end{tabular}

Each experiment consisted of $100 \mu \mathrm{l}$ of serially diluted lectin in U-shaped microtitre wells. To each well was added $50 \mu$ of 0.2 $\mathrm{M}$ sugar solution in PBS and $50 \mu \mathrm{l}$ of $4 \%$ suspension of type B red blood cells.

lectin is similar to those of Trichosanthes anguina seeds, 45,000 Da (Anuradha and Bhide, 1999) Artocarpus integrifolia, 46,000 Da, and Maclura pomifera, 44,000 Da (Moreira et al., 1998).

Carbohydrate content A sugar analysis revealed that $K$. crenata lectin is a glycoprotein since it stained purplish pink with Schiffs reagent after PAGE. An application of the modified anthrone reaction method of Jermyn (1975) further showed that there are approximately three molecules of sugar residues that are covalently bound to a molecule of the protein.

Molecular stability The lectin is remarkably stable in the $\mathrm{pH}$ range of 2-7.5. The activity, however, falls off fairly rapidly thereafter, with essentially all activity lost after $\mathrm{pH} 9.2$ (Fig. 3). It is possible that changes in the ionisation state with an increase in $\mathrm{pH}$ may lead to a weaker binding of the metal ions, which are apparently required for the maintenance of the structure that is required for maximal activity (vide supra). The $\mathrm{pH}$ dependence, which is observed in virtually all enzyme reactions, is a consequence of the protein composition. Numerous ionisable groups at the surface of the protein molecule and the active center are capable of reacting with $\mathrm{H}^{+}$ or $\mathrm{OH}^{-}$. Any $\mathrm{pH}$ change is therefore associated with a change in the ionization state of the molecule, which in turn, determines the binding forces between enzyme and substrate (Adolph and Lorenz, 1982). It is also possible that the increase in $\mathrm{OH}^{-}$ions caused a change in the ionization state of the lectin, thereby affecting the binding forces between the lectin and the erythrocyte membrane that eventually led to a
Table 3. Effect of EDTA and divalent cations on haemagglutinating activity

\begin{tabular}{cc}
\hline Experiment & Titre \\
\hline PBS control & $2^{6}$ \\
PBS containing $5 \mathrm{mM} \mathrm{EDTA}$ & $2^{3}$ \\
PBS+5 mM EDTA+10 $\mathrm{mM} \mathrm{MgSO}_{4}$ & $2^{8}$ \\
PBS+5 mM EDTA+10 $\mathrm{mM} \mathrm{MnSO}_{4}$ & $2^{7}$ \\
PBS+5 mM EDTA+10 $\mathrm{mM} \mathrm{BaCl}_{2}$ & $2^{8}$ \\
PBS+5 mM EDTA+10 $\mathrm{mM} \mathrm{MnCl}_{2}$ & $2^{7}$ \\
\hline
\end{tabular}

Each experiment consisted of (i) $0.1 \mathrm{ml}$ of lectin serially diluted with PBS and $50 \mu \mathrm{l}$ of $4 \%$ suspension of type O red blood cells, (ii) $0.1 \mathrm{ml}$ of lectin serially diluted with PBS containing $5 \mathrm{mM}$ EDTA and $50 \mu \mathrm{l}$ of $4 \%$ suspension of type O red blood cells, and (iii) $0.1 \mathrm{ml}$ of lectin serially diluted with PBS containing 5 $\mathrm{mM}$ EDTA, $10 \mathrm{mM}$ of divalent cation, and $50 \mu \mathrm{l}$ of $4 \%$ suspension of type $\mathrm{O}$ red blood cells.

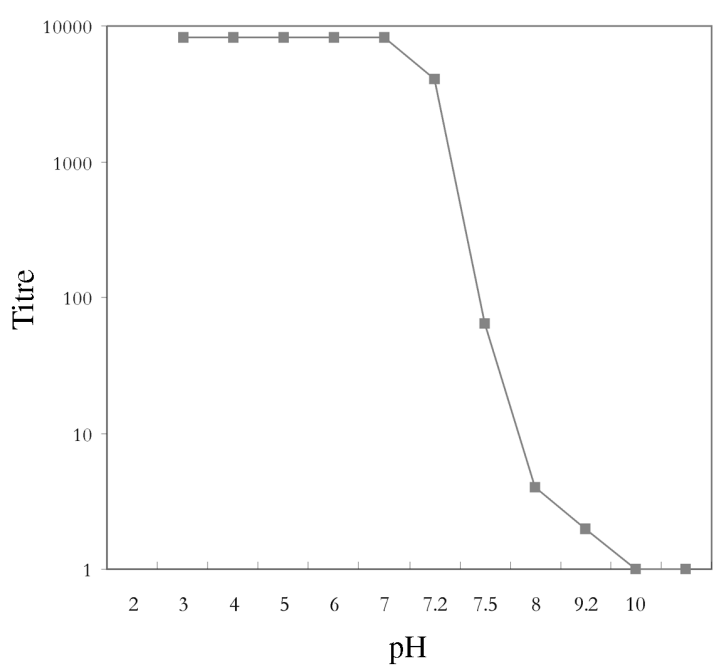

Fig. 3. Effect of $\mathrm{pH}$ on haemagglutinating activity. The buffers used were $0.2 \mathrm{M}$ citrate-phosphate $\mathrm{pH} 3-7.2,0.2 \mathrm{M}$ borate $\mathrm{pH}$ 7.5-9.5, 0.2 M glycine- $\mathrm{NaOH} \mathrm{pH} 10-12$.

loss of activity. The lectin of $P$. filicina was also stable in the $\mathrm{pH}$ range of 4-9, retaining 50\% of its activity at $\mathrm{pH} 3$ and 10, and $25 \%$ of its activity at pH 11-12 (Sampaio et al., 1998). The lectin from Parkia javanica beans also depended on $\mathrm{pH}$. The optimal $\mathrm{pH}$ value was 7 . It was stable in the $\mathrm{pH}$ range of 7-10. Also, more acidic or basic pHs decreased both the stability and activity (Utarabhand and Akkayanont, 1995).

In addition, $K$. crenata lectin is heat-stable up to $90^{\circ} \mathrm{C}$. As reported, the haemagglutinating activity of Hevea brasiliensis lectin (Wittsuwannakul et al., 1998) was heat-stable up to $60^{\circ} \mathrm{C}$ and $P$. filicina up to $50^{\circ} \mathrm{C}$ (Sampaio et al., 1998).

Acknowledgments This research work was supported by grant (number $1425 \mathrm{UX}$ ) from the Obafemi Awolowo University Research Committee (URC) of the Obafemi Awolowo University, Ile- Ife, Nigeria. 


\section{References}

Adeyemi, A., Togun, R. A., Ogunbiyi, O. A. and Aboderin A. (1994) Observations on the Haemagglutinins from the seeds of Dioclea reflexa (Hook). Nigerian J. Biochem. 9, 26-36.

Adolph, L. and Lorenz, R. (1982) Enzyme Diagnosis in Diseases of the Heart, Liver and Pancreas, John Wiley and Sons Inc., New York, USA.

Anuradha, P. and Bhide, S. V. (1999). An isolectin complex from Tricosanthes anguina seeds. Phytochem. 52, 751-758. 1.

Bing, D. H., Weyand, J. G. M. and Stavitsky, A. B. (1967) Heamagglutination with aldehyde fixed erythrocytes for assay of antigens and antibodies. Proc. Soc. Exp. Biol. Med. 124, 1166-1170.

Cavada, B. S., Santos, C. F., Grangeiro, B. T., Ramos, R. L. and Calvete, J. J. (1998) Purification and characterization of a lectin from seeds of Vatainea macrocarpa. Phytochem. 49, 675-680

Dalziel, J. M. (1955) The Useful Plants of West Tropical Africa, Millibank, London, UK.

Dong, T. X., Ng, T. B., Wong, R. N. S., Yeung, H. W. and Xu, G. J. (1993) Investigation of haemagglutinating activity in seeds of various Tricosanthes Species. Internat. J. Biochem. 25, 411414.

Goldstein, I. J. and Poretz, R. D. (1986) Isolation, physicochemical characterization and carbohydrate-binding specificity of lectins; in The Lectins: Properties, Functions and Applications in Biology and Medicine, Liener, I. E., Sharon, N. and Goldstein, I. J. (eds.), Academic Press Inc., Orlando, USA.

Gornall, A. G., Bardwill, C. J. and David, M. M. (1949) Determination of serum proteins by Biuret reaction. J. Biol. Chem. 177, 751-766.

Hayes, C. E. and Goldstein, I. J. (1974) An $\alpha$-D-galactosylbinding lectin from Bandeiraea simplicifolia seeds-isolation by affinity chromatography and characterization. J. Biol. Chem. 249, 1904-1914.

Jermyn, M. A. (1975) Increasing the sensitivity of the anthrone method for carbohydrate analysis. Biochemistry 68, 322-335.

Knight, C. S. (1967) Improved techniques with advanced ionexchange cellulose. Adv. Chromat. 4, 61-63.

Kuku, A., Stoppini, M., Cobianchi, A., Minetti, G., Balduini, C. and Aboderin, A. (2000) The complete primary structure of a mannose/glucose specific lectin from the seeds of Dioclea reflexa (Hook, F.) Nig. J. Biochem. Mol. Biol. 15, 115-119.

Lis, H. and Sharon, N. (1989) Lectins in higher plants; in Biochemistry of Plants, Vol. 6, pp. 371-447. Academic Press Inc, New York, USA.

Lotan, R., Skutelsky, E., Danon, D and Sharon, N. (1975) The purification, composition and specificity of the antiT lectin from peanut (Arachea hypogea). J. Biol. Chem. 250, 85188523.

Moreira, A. R., Castelo-Branco, C. C, Monteiro, A. C. O., Tavares, R. O. and Beltramini, L. M. (1998) Isolation and partial characterization of a lectin from Artocarpus incisa seed. Phytochem. 47, 1183-1188.

Presant, C. A. and Kornfeld, S. (1972) Characterisation of the cell surface receptor for the Agaricus bisporus heamagglutinin. $J$. Biol. Chem. 247, 6937-6945.

Pusztai, A. (1993) Dietary lectins are metabolic signals for the gut and modulate Immune and hormone functions. Eur. J. Clin. Nutr., 47, 691-699.

Sampaio, A. H., Rogers, D. S. J. and Barwell, C. J. (1998) A galactose-specific lectin from the red marine alga, Ptilota filicina. Phytochem. 48, 765-769.

Sharon, N. (1993) Lectin-carbohydrate complexes of plants and animals: An atomic view. Trends Biochem. Sci. 18, 221-226.

Shyamasri, B. and Arvind, M. K. (2002) Thermal stability of Phaseolus vulgaris leucoagglutinin: A differential scanning calorimetry. J. Biochem. Mol. Biol. 35, 472-475.

Togun, R. A., Animashaun, T., Binutu, O. and Aboderin, A. (1994) $\beta$-Galactosidase binding lectins from the seeds of Tetracarpidium conophorum (Mull. Arg. Hutch and Dalz.) (Euphorbiaceae). Nigerian J. Biochem. 9, 45-53.

Utarabhand, P. and Akkayanont, P. (1995) Purification of a lectin from Parkia javanica beans. Phytochem. 38, 281-285.

Watkins, W. M., Yates, A. D. and Greenwell, P. (1981) Blood group antigens and the enzymes involved in their syntheses, past and present. Trans. Biochem. Soc. 9, 186-191

Wittsuwannakul, R., Wittsuwannakul, D. and Sakulborirug, C. (1998) A lectin from the bark of the rubber tree (Hevea brasiliensis). Phytochem. 47, 183-187. 